\title{
Evaluation of Some Environmentally Safe Cemicals Against Spodoptera littoralis
}

\author{
Ismail, Seham M., ${ }^{1}$ M. Morshedy ${ }^{2}$
}

\begin{abstract}
Toxicity effect of Dipel-2X, and three insect growth regulators IGRs: Diflubenzuron; Spiromesifen and Pyriproxyfen, were determined against $2^{\text {nd }}$ larval instar of Spodoptera littoralis. The results showed that Diflubenzuron was the most potent toxicity followed by Spiromesifen; Pyriproxyfen, and Dipel-2X. The effect of $\mathrm{LC}_{50}$ of the tested IGRs on the in vivo inhibition of chitinase from Spodoptera littoralis was assayed. The interaction effect of Dipel-2X with IGRs was investigated. Results proved that pretreated of Dipel-2X with IGRs caused more toxicity effect than single treatment. The sensitivity of chitinase activity to the three tested IGRs was measured by the $I_{50}$ values. The $I_{50}$ values of Diflubenzuron; Spiromesifen and Pyriproxyfen on Lab strain larval chitinase are $0.54,0.60$ and $0.73 \mu \mathrm{M}$ respectively. While the $I_{50}$ values are $0.60,0.72$ and $0.81 \mu \mathrm{M}$ respectively against Field strain. The results proved that chitinase was sensitive to the IGRs. Generally, Dipel-2X pretreated with IGRs will produce a new trend so as increase toxicity of the bioinsecticide, enhance the role of beneficial insects. The results of the present study may add some forward steps to use bioinsecticide as alternative to conventional insecticides especially against this insect. So, the tested compounds can be involved in important steps necessary for successful IPM programmes applied against $S$. littoralis.
\end{abstract}

\section{INTRODUCTION}

The Egyption cotton leafworm, Spodoptera littoralis is one of the major pests in the middle east. It has quickly developed resistance to chemical pesticides (Chung and Cote, 1992 \& Amin, et al., 2001). Therefore, the cotton leafworm in Egypt exhibits multiple resistance to nearly all insecticides used (Keddis, et al., 1988 \& Ishaaya and Kleen, 1990).Owing to the endless and various problems that have been arisen by using insecticides (eg., the development of pest resistance, rapid resurgence of target species and outbreaks of secondary pests), the need to develop novel alternatives or functional combinations of pest control techniques is emphatically a product of this decade. Attention was therefore paid to control insects using different non traditional insecticides, e.g., insect growth regulators (IGRs) and Bacillus thuringiensis (BT). (Klein, et al., 1996; AbdelHalim, 1997 \& Rizk, et al., 1999).
IGRs show good effect against scale insects on cotton. Their effects have been observed in development, on behavior and several forms of diapauses. Also IGRs compounds which are considered nowadays one of the mainly component of IPM program term IGRs describe a new class of bio-rational compounds. (Mesbah, et al., 1982; Abdel-Naby, et al., 1990; Palma and Meola, 1993; Pawar, et al., 1995 \& Shiotsuki, et al., 1999).

In recent years, much attention has been paid to the use of the Bacillus thuringiensis (B.t.) against Spodoptera littoralis (Lecadet and Martouret, 1987; Entwistle, et al., 1993; Klein, et al., 1996 \& AbdelHalim, 1997). Bacillus thuringiensis subsp. Kurstaki active vs. lepidopterous insects (Lereclus, et al., 1989). The mixtures of $\mathrm{Bt}$. with some insecticides have been evaluated against various insects. (Pree and Daly, 1996 \& Abou-Taleb, 2000).

The present investigation aimed to study the efficiency of bioinsecticide (Diple-2X) either alone or in their combination with some IGRs (Diflubenzuron; Spiromesifen and Pyriproxyfen) on Spodoptera larvae. Also the study was directed to throw the light on the effect of these tested IGRs on the activity of chitinase.

\section{MATERIALS AND METHODS} Insect:

Laboratory strain of cotton leafworm, Spodoptera littoralis was chosen for bioassays and biochemical assessment. This strain start as field strain reared under laboratory condition for several years in centeral lab. of pesticides, Agricultural Research Center (ARC) Cairo, Egypt. Field strain of Spodoptera littoralis egg masses were collected from cotton fields at Abeis area, the $2^{\text {nd }}$ larval instar used for assessments.

\section{Chemical:}

Three IGRs insecticides: Diflubenzuron, 25\% (WP) Novartis Co. (Syngenta). Spiromesifen, 24\% (SC); was obtained from MyTrade Co., and Pyriproxyfen, $10 \%$ (EC) was obtained from Sumitomo Chemical Co.

Bioinsecticide Bacillus thuringiensis subsp. Kurstaki; Diple-2X 6.4\% (WP) (32,000 International Units/mg). The product was produced by Abbott Laboratories. Chemical and Agricultural Products

\footnotetext{
${ }^{1}$ Central Laboratory of Pesticides, Sabahia, Alexandria, A.R.C.

${ }^{2}$ Pesticide Chemistry Dept., Fac. of Agrie., Alex., Univ.

Received March15, 2009, Accepted March30, 2009
} 
Division, North Chicago, USA, and Provided by Bayer Company.

\section{Bioassay tests:}

\section{1-Toxicity of Bt.:}

Second instar larvae were starved for 6hrs before exposed test. The selected larvae were bioassayed against commercial strain (Diple-2X). Using three replicates for each concentration with ten larvae in each replicate.

Disc dipping technique was used since it has been proved to be the most common procedure for assessing toxicity to commercial formulation of Bt. (Tabashnik and Cushing, 1987). Each castor leaves disc $\left(2 \mathrm{Cm}^{2}\right)$ was dipped into the suspension of tested formulation for 10s. Tested concentration were prepared in glass distilled water (GDW) (Toni and Fred, 1996) discs were held vertically to allow excess solution to drip off and placed on a rack to dry for at least $2 \mathrm{hr}$. Treated discs were offered to starved larvae (on disc per cup) and left under constant conditions $\left(27 \pm 2{ }^{\circ} \mathrm{C}\right)$. There after survivors were transferred with fresh castor oil plant leaves to clean cups and kept under the same conditions. Control larvae were allowed to fed on castor oil leave discs treated with distilled water. Mortality was percentage calculated for each concentration daily for $24 ; 48$, and $72 \mathrm{hrs}$ and corrected according to Abbott (1925) and subjected to probit analysis using the computer program (Finney, 1971).

\section{2-Toxicity of the Tested IGRs Against $S$. littoralis:}

Diflubenzuron; Spiromesifen and Pyriproxyfen, were bioassayed against the $2^{\text {nd }}$ larval instar $S$. littoralis. The castor leaves were dipped in different concentrations of the tested IGRs. All insecticides concentrations were prepared in distilled water. The treated leaves were placed in clean glass container at the laboratory conditions of $\left(27 \pm 2^{\circ} \mathrm{C}\right)$ and $65-70 \% \mathrm{RH}$. Ten larvae (Lab and Field strains) were used for each test with three replicate. Mortality was recorded after 24; 48 and $72 \mathrm{hr}$ and subjected to probit analysis.

\section{3-Toxicity of Tested Diple-2X in Presence of IGRs:}

S. littoralis $2^{\text {nd }}$ instar (Lab and Field strains) were treated with solution of Diflubenzuron; Spiromesifen and Pyriproxyfen at $\mathrm{LC}_{50}$ values concentrations before 24; 48 and $72 \mathrm{hr}$ of feeding on discs of castor oil leaves discs treated with $\mathrm{LC}_{50}$ of Diple-2X, joint action experiments have tow controls. Larvae of the first control were allowed to fed castor oil leaf discs treated with concentration equivalent $\mathrm{LC}_{50}$ of Diple- $2 \mathrm{X}$ alone, while larvae of the second control were fed with untreated discs. Mortality counted and recorded daily for 3days. Percentage of mortality were calculated according to Abbott (1925) and subjected to probit analysis (Finney, 1971).

\section{Enzyme Preparation and Activity Assay:}

Chitinase was prepared from S. littoralis. $2^{\text {nd }}$ instar larvae (Lab and Field strains) according to the method of Deul, et al., (1978). Homogenate was prepared in $10^{-}$ ${ }^{3} \mathrm{M}$ Cleland's reagent (dithiotheritol, DTT) (v/w=2). The homogenate was centrifuged for $15 \mathrm{~min}$ at $12,000 \mathrm{~g}$. An equal volume of saturated ammonium sulfate solution was slowly added to the supernatant. After stirring for $1 \mathrm{hr}$, the suspension was centrifuged for $10 \mathrm{~min}$ at $10,000 \mathrm{~g}$. The precipitate was washed with halfsaturated ammonium sulfate solution and was recentrifuged, after which it was suspended in a small volume of water, followed by dialysis $20 \mathrm{hr}$. Any occasional precipitate was removed by centrifugation and was discarded as it proved to be enzymatically inactive. After dialysis, water was added to the original ratio $(\mathrm{v} / \mathrm{w}=2)$. All manipulations were carried out at 0 2?C.

Chitinase activity was determined according to the method of Reissig, et al., (1955) which modified by Andrew, et al., (1982), using sodium acetate buffer instead of tris-HCl buffer and wave-leangth $416 \mathrm{~nm}$ was used instead of $544 \mathrm{~nm} .25 \mu \mathrm{l}$ of chitin $(20 \mathrm{mg} / \mathrm{ml}), 100 \mu \mathrm{l}$ of enzyme prep and $225 \mu$ l of sodium acetate buffer, $(\mathrm{pH}$ $4.5)$ in total volume $350 \mu$. The enzyme substrate mixture was incubated at 35 ? for $60 \mathrm{~min}$, then the reaction was stopped by adding $100 \mu 1$ of $0.8 \mathrm{M}$ borate buffer $(\mathrm{pH} 10.0)$ followed by determination of $\mathrm{N}$ acetylglucoseamine by the method of Reissig, et al., (1955). By adding $1.5 \mathrm{ml}$ of p-dimethyl amino benzaldhyde (DMAB, reagent). The samples were incubated in a shaker water bath at $35 ? \mathrm{C}$ for $20 \mathrm{~min}$, the samples were measured spectrophotometerically at $\lambda 416 \mathrm{~nm}$.

The protein content of $S$. littoralis $2^{\text {nd }}$ instar larvae homogenates was assayed spectrophotometrically by the method of Lowery, et al., (1951) at $\lambda 750 \mathrm{~nm}$ using bovine serum albumin as a standard protein.

\section{Inhibition of Chitinase Activity:}

The inhibition of chitinase was determined in $2^{\text {nd }}$ instar larvae $S$. littoralis using the $\mathrm{LC}_{50}$ values of each of the three tested IGRs. The method of Dixon and Webb, (1964) was adopted to draw the Dixon-plots by plotting $1 / \mathrm{V}$ versus concentrations of the inhibitor at two concentrations of the substrate. Chitine (the substrate of chitinase) concentrations were 3.0 and $5.0 \mathrm{mM}$. Estimation of $\mathrm{I}_{50}$ value (the concentration of the inhibitor which inhibits $50 \%$ of the enzyme activity) was carried out by pre incubating the enzyme with the inhibitor for $30 \mathrm{~min}$. 


\section{RESULTS AND DISCUSSIONS}

\section{Toxicity of Dipel-2X and Three IGRs:}

The results of the toxicity of the Dipel-2X and IGRs in terms of $\mathrm{LC}_{50}$ are given in Table (1) for $2^{\text {nd }}$ instar larvae of $S$. littoralis. LC $_{50}$ values after $24 \mathrm{hr}$ were 7.31, 3.62, 4.25 and 5.38ppm for Dipel-2X, Diflubenzuron, Spiromesifen and Pyriproxyfen, respectively against Spodoptera Lab strain. For Field strain, $\mathrm{LC}_{50}$ values were $9.44,4.39,5.66$ and $6.17 \mathrm{ppm}$ respectively. While $\mathrm{LC}_{50}$ values after $48 \mathrm{hr}$ were 5.40, $1.22,3.41$ and 4.00ppm respectively against Lab strain. For Field strain, the $\mathrm{LC}_{50}$ were $7.36,2.16,3.02$ and $4.40 \mathrm{ppm}$ respectively. $\mathrm{LC}_{50}$ values after $72 \mathrm{hr}$ were 1.23 , $0.23,0.44$ and $0.74 \mathrm{ppm}$ respectively against Lab strain. For Field strain, the $\mathrm{LC}_{50}$ were $2.13,0.45,0.68$ and $0.91 \mathrm{ppm}$ respectively. According to the $\mathrm{LC}_{50}$ values, it is quite clear that the susceptibility of Spodoptera larvae to Dipel-2X, and the Lab strain of Spodoptera larvae is more susceptible to Dipel-2X in comparison to the Field strain. Also IGRs may act as growth distruptor, it interferes with moulting by softening the larval endocuticle through reduction in its chitin content and by hardening of the exocuticle as result of enhanced phenoloxidase activity. These results are in agreement with many investigators, Dulmage, 1971; Ibrahim, 1974; Ascher and Nemny, 1979; Dimetry, et al., 1979; Grosscurt and Anderson, 1980; Radwan, et al., 1980; El-Sayed, 1981; El-Nockrashy, et al., 1986; Lecadet and Martouret, 1987; Marguerre-M and Daniel, 1987; Chilcott and Ellar, 1988; Chung and Cote, 1992; Fisk and Wright, 1992; Tabashnik, 1992; Chandler, 1993; Palma and Meola, 1993; Forrester, 1994; El-Kordy, et al., 1995; Pawar, et al., 1995; Smagghe, et al., 1997; Barker, 1998; Said, 1998; Abd-Allah, 2000; AbouTaleb, 2000; Ali, 2001 \& El-Aw, 2006.

Toxicity of Dipel-2X Alone or Pretreated with the $\mathbf{L C}_{50}$ Values of IGRs Against $\boldsymbol{S}$. littoralis Larvae:

Data in Table (2) show the $\mathrm{LC}_{50}$ values of Dipel-2X are $7.31,5.40$ and $1.23 \mathrm{ppm}$ after $24 ; 48$ and $72 \mathrm{hr}$ against Lab Spodoptera strain respectively, while the $\mathrm{LC}_{50}$ values are 9.44, 7.36 and 2.13ppm against Field Spodoptera strain respectively. The interaction of IGRs Table 1. $\mathrm{LC}_{50}$ values of Dipel-2X and three IGRs to $2^{\text {nd }}$ with Dipel-2X against Lab and Field strains of Spodoptera larvae were studied. Larvae were allowed to feed on castor oil leave discs treated with $\mathrm{LC}_{50}$ of the different IGRs.

The $\mathrm{LC}_{50}$ values, of Dipel-2X pretreated with the $\mathrm{LC}_{50}$ values of Diflubenzuron; Spiromesifen and Pyriproxyfen on Lab and Field strains of Spodoptera larvae are presented in Table (2). The $\mathrm{LC}_{50}$ values of Dipel-2X when pretreated with IGRs was lower than $\mathrm{LC}_{50}$ of Dipel-2X alone in Lab or Field Spodoptera strains. The enhancement of toxicity is calculated as a Potentiation factor (P.f.) Table (2). Potentiation factor (P.f.) values for Diflubenzuron; Spiromesifen and Pyriproxyfen are 13.54, 11.97 and 9.14 respectively, after $24 \mathrm{hr}$ for Lab strain, while the P.f. values of three IGRs are 13.88, 12.26 and 10.04 respectively, after $24 \mathrm{hr}$ treatment, for Field strain. The P.f. values of three IGRs are $16.36,13.17$ and 8.57 respectively, after $48 \mathrm{hr}$ for Lab strain, while the P.f. values for Field strain are 13.63, 12.07 and 10.51 for three IGRs respectively. While the P.f. values of three IGRs are 9.68, 6.87 and 5.33 respectively, for Lab strain after $72 \mathrm{hr}$ treatment, while the P.f. values for Field strain are 13.33, 9.52 and 7.41 for three IGRs respectively. It is clear that the $\mathrm{LC}_{50}$ values concentrations of IGRs enhancement the toxicity of the Dipel-2X on $S$. littoralis larvae. The mixtures of Diflubenzuron+Dipel-2X were the most toxic treatments than Spiromesifen+Dipel-2X and Pyriproxyfen+Dipel-2X respectively.

In general, the susceptibility of Spodoptera larvae to Dipel-2X increases when treatment after IGRs. The IGRs+Dipel-2X caused more toxic effect than single treatment with Dipel-2X, it could be concluded that IGRs enhanced the toxicity effect of Dipel-2X. Based on P.f. values, the Lab strain of Spodoptera larvae is more susceptible to Dipel-2X in comparison to the Field strain. Generally, efficacy of IGRs have a very good additive toxicity for Dipel-2X either in Lab or Field Spodoptera strains. These results are agreement with finding (Salama, et al., 1992; David and Joanne, 1996; Klein, et al., 1996; Pree and Daly, 1996; Liburd, et al., 2000 \& Mona, et al., 2004) whom found that when certain pairs of drugs or insecticides are administered

instar S. littoralis larvae

\begin{tabular}{lcccccc}
\hline \multirow{2}{*}{ Compounds } & \multicolumn{5}{c}{ LC $_{\mathbf{5 0}}(\mathbf{p p m})$} \\
\cline { 2 - 7 } & \multicolumn{2}{c}{$\mathbf{2 4 h \mathbf { h r }} \mathbf{4 8 h r}$} & \multicolumn{2}{c}{$\mathbf{7 2 h \mathbf { ~ }}$} \\
\cline { 2 - 7 } & Lab strain & Field strain & Lab strain & Field strain & Lab strain & Field strain \\
\hline Dipel-2X & 7.31 & 9.44 & 5.40 & 7.36 & 1.23 & 2.13 \\
Diflubenzuron & 3.62 & 4.39 & 1.22 & 2.16 & 0.23 & 0.45 \\
Spiromesifen & 4.25 & 5.66 & 3.41 & 3.02 & 0.44 & 0.68 \\
Pyriproxyfen & 5.38 & 6.17 & 4.00 & 4.40 & 0.74 & 0.91 \\
\hline
\end{tabular}


Table 2. Comparative toxicities of Dipel-2X alone or pretreated with three IGRs on Spodoptera larvae

\begin{tabular}{|c|c|c|c|c|c|c|c|c|c|c|c|c|}
\hline \multirow{3}{*}{ Compounds } & \multicolumn{12}{|c|}{$\mathbf{L C}_{50}(\mathbf{p p m})$} \\
\hline & \multicolumn{4}{|c|}{$24 \mathrm{hr}$} & \multicolumn{4}{|c|}{$48 \mathrm{hr}$} & \multicolumn{4}{|c|}{$72 \mathrm{hr}$} \\
\hline & $\begin{array}{c}\text { Lab } \\
\text { strain }\end{array}$ & P.f. & $\begin{array}{c}\text { Field } \\
\text { strain }\end{array}$ & P.f. & $\begin{array}{c}\text { Lab } \\
\text { strain }\end{array}$ & P.f. & $\begin{array}{c}\text { Field } \\
\text { strain }\end{array}$ & P.f. & $\begin{array}{c}\text { Lab } \\
\text { strain }\end{array}$ & P.f. & $\begin{array}{c}\text { Field } \\
\text { strain }\end{array}$ & P.f. \\
\hline Dipel-2X & 7.31 & & 9.44 & & 5.40 & & 7.36 & & 1.23 & & 2.13 & \\
\hline $\begin{array}{c}\text { Diflubenzuron } \\
+ \text { Dipel-2X } \\
\end{array}$ & 0.54 & 13.54 & 0.68 & 13.88 & 0.33 & 16.36 & 0.54 & 13.63 & 0.22 & 9.68 & 0.30 & 13.33 \\
\hline $\begin{array}{c}\text { Spiromesifen } \\
\text { +Dipel-2X }\end{array}$ & 0.61 & 11.97 & 0.77 & 12.26 & 0.41 & 13.17 & 0.61 & 12.07 & 0.31 & 6.87 & 0.42 & 9.52 \\
\hline $\begin{array}{c}\text { Pyriproxyfen } \\
\text { +Dipel-2X }\end{array}$ & 0.80 & 9.14 & 0.94 & 10.04 & 0.63 & 8.57 & 0.70 & 10.51 & 0.40 & 5.33 & 0.54 & 7.41 \\
\hline
\end{tabular}

*Potentiation factor (P.f.) $=\mathrm{LC}_{50}$ Dipel-2X alone / LC $\mathrm{L}_{50}$ IGRs + Dipel-2X

together, the effects may be greater or less than might be expected from the sum of the activities of the components when administered separately. The

phenomena involved, included under the term "synergism" "potentiation" and "antagonism", are becoming increasingly important in, for example, practical insect control and mammalian toxicology.

The observation that Dipel-2X had the lowest effect when applied alone but it was the best when mixed with IGRs. These findings may be resulted insect cuticle easily penetration which caused by IGRs in the mixture, and these results show that IGRs are act in similar manner in reducing chitin incorporation in the cuticle of S. Littoralis. So these mixture are a good control of Lepidopterous larvae.

Generally, it could be concluded that the use of insect growth regulators (IGRs) and their mixtures with biological insecticides (Dipel-2X) instead of conventional hazardous insecticides; and these my reduce the environmental pollution and hazard effects on human health. Dipel-2X may play an important role in future insect pest management programs especially when mixed with IGRs.

\section{In Vivo Inhibition of S. littoralis Chitinase Activity:}

The in vivo inhibition effect of the $\mathrm{LC}_{50}$ values three IGRs against to the Spodoptera $2^{\text {nd }}$ instar Lab and Field strains larval chitinase is shown in the data given in Table (3). The data declared that Diflubenzuron; Spiromesifen and Pyriproxyfen exhibited the high percentages of reduction of chitinase activity as values were $87.2,80.5$ and $75.4 \%$ respectively, for Lab strain, while values were $80.6,76.9$ and $70.5 \%$ respectively, for Field strain. Results indicated that Diflubenzuron in more effect on the chitinase activity than the Spiromesifen and Pyriproxyfen on $2^{\text {nd }}$ instar. It is quite clear that the IGRs at $\mathrm{LC}_{50}$ concentration acts as potential inhibitors for Spodoptera larvae chitinase activity.

Table 3. In vivo inhibition of Spodoptera larvae $2^{\text {nd }}$ instar Chitinase activity by $\mathrm{LC}_{50}$ of three IGRs

\begin{tabular}{ccc}
\hline \multirow{2}{*}{ IGRs } & \multicolumn{2}{c}{ \%Inhibition } \\
\cline { 2 - 3 } & Lab strain & Field strain \\
\hline Diflubenzuron & 87.2 & 80.6 \\
Spiromesifen & 80.5 & 76.9 \\
Pyriproxyfen & 75.4 & 70.5 \\
\hline
\end{tabular}

In Vitro Inhibition of $S$. littoralis Chitinase Activity:

Table (4) show the in vitro inhibition of IGRs on chitinase activity of $S$. littoralis $2^{\text {nd }}$ instar. The $\mathrm{I}_{50}$ values of Diflubenzuron; Spiromesifen and Pyriproxyfen for Lab strain larval chitinase are $0.54,0.60$ and $0.73 \mu \mathrm{M}$ respectively. While the $I_{50}$ values are $0.60,0.72$ and $0.81 \mu \mathrm{M}$ respectively against Field strain. To characterize more details about the in vitro inhibition of chitinase by the inhibitor, the $\mathrm{I}_{50}$ and $\mathrm{Ki}$ values of each inhibitor were estimated from the graphical method of Dixon and Webb, (1964) Table (4). The obtained data proved that IGRs competitive inhibition of chitinase activity and $\mathrm{Ki}$ values were 40.0 and $15.0 \mu \mathrm{M}$ for Lab and Field strains respectively, in the case of Diflubenzuron. While these values were 52.0 and 18.0 $\mu \mathrm{M}$ for Lab and Field strains respectively, in the case of Spiromesifen. On the other hand, Ki values were 61.0 and $56.0 \mu \mathrm{M}$ for Lab and Field strains respectively, in case of Pyriproxyfen.

In conclusion, Chitinase plays an essential role during ecdysis chitin. This enzyme is vital to moulting in insects, and may also affect gut physiology through their involvement in peritrophic membrane turnover. The exoskeleton of insects might constitute a useful target site for insecticidal chemicals. 
Table 4. In vitro inhibition of Spodoptera larvae Chitinase activity by some IGRs

\begin{tabular}{ccccc}
\hline \multirow{2}{*}{ IGRs } & \multicolumn{2}{c}{$\mathbf{I}_{\mathbf{5 0}}(\boldsymbol{\mu M})$} & \multicolumn{2}{c}{$\mathbf{K i}(\boldsymbol{\mu M})$} \\
\cline { 2 - 5 } & Lab strain & Field strain & Lab strain & Field strain \\
\hline Diflubenzuron & 0.54 & 0.60 & 24 & 30 \\
Spiromesifen & 0.60 & 0.72 & 33 & 44 \\
Pyriproxyfen & 0.73 & 0.81 & 42 & 56 \\
\hline
\end{tabular}

\section{REFERENCES}

Abbott, W. S. (1925). A method for computing the effectiveness of an insecticide. J. Econ. Entomol., 18: 265-267.

Abd-Allah, S. M. A. (2000). Bacillus thuringiensis (B.t.), Bioinsecticidal toxin agent: protein purification and study mode of action. Ph. D. Thesis. Faculty of Science, Alex. University.

Abdel-Halim, S. M. (1997). Efficacy and residual effect of some microbial and chemical insecticides against the cotton leafworm, Spodoptera littoralis. (Boisd). Egyptian J. of Biological Pest Control. 7: 71-76.

Abdel-Naby, L. M.; M. R. Farrag, and M. F. El-Sheikh (1990). Biological effects of two insect growth regulators on the Egyptian cotton leafworm Spodoptera littoralis (Boisd.). J. of Agri-Sci. Mansoura Univ. (Egypt). 13: 328-333.

Abou-Taleb, H. K. (2000). Corn integrated insect management, Managing corn borers by Bacillus thuringiensis in the field. M. Sci. Thesis. Faculty of Agriculture, Alex. University.

Ali, G. F. (2001). Toxicological studies on pesticide alternatives. M. Sc. Thesis submitted to Alex. University.

Amin, A. A. A.; M. Gergis, and M. El-Naggar (2001). Alternative in field refuge strategies for controlling certain cotton key pests in middle Egypt. The ESA 2001 Annual Meeting-December 2001: An Entomological Odyssey of ESA, San Diego, CA.

Andrew, C. C.; Mayer, R. T., and De-loach, J. R. (1982). Purification and characterization of chitinase from the stable fly Stomoxys calcitrans. Arch. Biochem. Biophys., 216: 314-321.

Ascher, K. R. S., and N. E. Nemny (1979). Toxcicity of chitin synthesis inhibitors diflubenzuron and its dichlorobenzoyl analogue to Spodoptera littoralis larvae. Pestic., Sci., 7: 1-9.

Barker, J. F. (1998). Effect of Bacillus thuringiensis supsp. Kurstaki toxin on the mortality and development of the larval stages of the banded sunflower moth (Lepidoptera: Cochylidae). J. Econ. Entomol., 9: 1084-1088.

Chandler, L. D. (1993). Use of feeding stimulants to enhance insect growth regulator induced mortality of the fall armyworm (Lepidoptera: Noctuidae) larvae. Florida Entomol., 76: 316-326.
Chilcott, C. N., and D. J. Ellar (1988). Comparative toxicity of Bacillus thuringiensis var israelensis crystal proteins in vivo and in vitro. J. Gen. Microbiol. 134: 2552- 2558.

Chung, Y. S., and C. J. Cote (1992). Crystal of Bacillus thuringiensis two mutants of show increased toxicity against larvae of Spodoptera littoralis. Entomophga, 37:193-196.

Deul, D. H.; De-Jong, B. J., and kortenbach. J. A. M. (1978). Inhibition of chitin synthesis by two 1-(2,6-disubstitut benzoyl)-3-phenylurea insecticides. Pesticide Biochemistry and Physiology. 8: 98-105.

Dimetry, Nadia Z., and M. A. Ramadan (1979). Effect of insect growth regulator on the cotton leafworm, Spodoptera littoralis (Boisd.). $3^{\text {rd }}$ Pest. Conf. Tanta Univ., 1: 85-91.

Dixon, M., and E. C. Webb (1964). Enzymes. Academic press, Inc., New York. $2^{\text {nd }}$ edition., 328-330.

Dulmage, H. T. (1971). A proposed standardizedn bioassay for formulations of Bacillus thuringiensis based on the international unit. J. Invertebr. Pathol., 18: 240-345.

El-Aw, A. M. (2006). Efficacy of two biorational insecticides, emamectin benzoate and spinosad, against the immature stages of the cotton leafworm, Spodoptera littoralis (Boisd.) (Lepidoptera: Noctuidae). Alex. J. Agric. Res., 51: 55-68.

El-Kordy, M. W.; A. I. Gadallah; M. G. Abas, and S. A. Mostafa (1995). Effect of Pyriproxyfen; flufenoxuron and teflubenzuron on some biochemical aspects of $S$. littoralis. A1-Azhar. J. Agric. Res., 21: 223-238.

El-Nockrashy, A. S.; H. S. Salama, and F. Taha (1986). Influence of bait formulations on the effectiveness of Bacillus thuringiensis against Spodoptera littoralis (Boisd.) (Lepidoptera: Noctuidae). J. Appl. Entomol., 101: 389-299.

El-Sayed, E. I. (1981). Effect of diflubenzuron and diflubenzuron hostathion combinations on larvae and adults of the Egyptian cotton leafworm, Spodoptera littoralis (Boisd.). Bull. Ent. Soc. Egypt, Econ. Ser., 12: 195-201.

Entwistle, P. M.; J. Baily; J. Cory, and S. Higgs (1993). Bacillus thuringiensis an environmental biopesticide wiley, New York. 172-185.

Finney, D. J. (1971). Probit analysis, $3^{\text {rd }}$ ed Cambridge Univ. Press, Cambridge, England. 
Fisk, T., and D. J. Wright (1992). Response of Spodoptera exempta (Walk.) larvae to stimulated field spray applications of acylurea insect growth regulators with observations on cuticular uptake of acylureas. Pesticide Since., 35: 331-337.

Forrester, N. W. (1994). Use of Bacillus thuringiensis in integrated control, especially on cotton pestes Agriculture, Ecosystems and Environment, 49: 77-83.

Grosscurt, A. C., and S. O. Anderson (1980). Effects of diflubenzuron on some chemical and mechanical properties of the eiytra Leptinatarsa decemlineata. Proc. Kon. Ned. Acad. Weteschappen. 83: 143-150.

Ibrahim, A. A. (1974). Studies on the biological control of Spodoptera littoralis (Boisd.) in A.R.E., Ph.D. Thesis Faculty of Agriculture. Cairo University. 282pp.

Ishaaya, I., and M. Kleen (1990). Response of susceptible laboratory and resistant field strains of Spodoptera littoralis (Lepi. Noct.) to teflubenzuron. J. Econ. Entomol., 83: 59-62.

Keddis, M. E.; A. F. Ayad; S. M. Abdel-Fattah, and A. M. ElGuindy (1988). Studies of resistance to urea derivites and their mixtures with insecticides in field strains of cotton leafworm, Spodoptera littoralis (Boisd.) during the cotton seasons 1983, 1984 and 1985. Bull. Ent. Soc. Egypt, Econ. Ser., 15: 229-234.

Klein, C. D.; R. D. Johnson; B. H. Myers, and M. L. Page (1996). Evaluation of Bacillus thuringiensis and ovicide combinations for bollworm and tobacco budworm. Proc. Beltwide Cotton Conf., Nashville, TN, USA, 2: 789-799.

Lecadet, M. M., and D. Martouret (1987). Host specificity of the Bacillus thuringiensis $\alpha$-endotoxin toward lepidopteran species: Spodoptera littoralis Bdv.And Pienis brassicael. J. Invert. Pathol., 49: 37-48.

Lereclus, D.; C. Bourgouin; M. M. Lecader; A. Klier, and G. Rapoport (1989). Role structure, and molecular organization of the genes coding for the parasporal $\delta$ endotoxins of Bacillus thuringiensis. In Regulation of prokaryotic development. (Smith, R. A. Slepecky, and Setlow, P. ed.). American Society for Microbiology, Washington. D. C. p.225-276.

Liburd, E. O.; J. E. Funderburk, and S. M. Olson (2000). Effect of biological and chemical insecticides on Spodoptera species (Lep., Noctuidae) and marketable yield of tomatoes. J. of Applied Entomol., 124: 19-25.

Lowery, H. O.; Rosbrough, N. J.; Farr, A. L., and Ranball, R. J. (1951). Protein measurement with the folin phenol reagent. J. Biol. Chem., 193: 265-275.

Marguerre-M, L., and M. Daniel (1987). Host specificity of the Bacillus thuringiensis $\delta$-endotoxin toward lepidopteran species: Spodoptera littoralis Bdv. and Pieris brassicae L. J. Invert. Pathol., 49: 37-48.

Mesbah, H. A.; A. N. Hassan; A. S. M. Radwan; A. R. M. Abdel-Mohymen, and A. S. M. Abdel-Fattah (1982). Synergism between certain adjuvants and two insect growth regulators against the larvae of the cotton leafworm Bull Ent. Soc. Egypt. Econ. Ser., 3: 25-30.
Mona, B. R. El-Mandarawy; Moustafa, A. Z. El-Naggar, and Saadia, A. Abdel-Samae (2004). Evaluation of Feeding stimulant mixed with chemical and bio insecticides on certain Lepidopterous pests and their natural enemies in cotton and soybean fields. J. Appl. Sci. Environ. Mgt., 8: 77-83.

Palma, K., and R. Meola (1993). Mode of action of pyriproxyfen and smethoprene on cat flea (Ctenocephalides felis) eggs. J. Med. Entomol., 421-426.

Pawar, P. V.; P. S. Pisale, and N. R. Sharma (1995). Effect of some new insect growth regulators on metamorphosis \& reproduction of Aedes aegypti. Indian J. Med. Res., 101: 8-13.

Pree, J. D., and C. J. Daly (1996). Toxicity of mixtures of Bacillus thuringiensis with endosulfan and other insecticides to the cotton bollworm Helicoverpa armigera. J. Pestic. Sci., 48: 199-204.

Radwan, H. S. A.; G. A. M. Rizk, and D. M. Assal (1980). The dose toxicity of certain insect growth regulators on cotton leafworm in relation to development inhibitory effect. (Proc. Arab Pest Conf., Tanta Univ., 1: 415-422).

Reissig, J. L.; Strominger, J. L., and Leloir, L. F. (1955). A modified colorimetric method for the estimation of $\mathrm{N}$ acetylamine sugars. J. Biol. Chem., 217: 959-966.

Rizk, M. A.; A. G. El-Sisi; N. A. Badr, and S. M. AbdelHalim (1999). Controlling of cotton sucking pests using safe materials. $2^{\text {nd }}$,Int. Conf. of Pest Control, Mansoura, Egypt, Sept., Special Proc., 211-221.

Said, A. M. (1998). Bioeffecacy of certain insect growth regulators on the black cutworm, Agrotis ipsilon (Hufu.) Egypt. J. Appl. Sci., 13: 113-120.

Salama, H. S.; M. S. Abd El-Baset, and M. Ragaei (1992). Mode of action of chemical additives in enhancing the potency of Bacillus thuringiensis against Lepidopterous insects. J. Appl. Entomol., 114: 167-173.

Shiotsuki, T.; F. Yukuhiro; M. Kiuchi, and E. Kuwano (1999). Effect of 1-(4-phenoxyphenoxyl) imidazole (KS-175) on larval growth in the silkworm Bombyx mori. J. Insect Phsiol., 45: 1040-1047.

Smagghe, G.; M. Auda; K. Laecke, and D. Van Degheele (1997). Significance of penetration and metabolism on topical toxicity of diflubenzuron in Spodoptera littoralis and Spodoptera exigua. Entomol. Exp. Et Applicata., 82: 255-260.

Tabashnik, B. E. (1992). Evaluation of synergism among Bacillus thuringiensis toxins. Appl. Environ. Microbiol., 58: 3343-3346.

Tabashnik, B. E., and L. N. Cushing (1987). Leaf residue vs. topical bioassays for assessing insecticide resistance in the diamond back moth Plutella xylostella. F. A. O. Plant Prot. Bull, 35: 11-14.

Toni, M., and G. Fred (1996). Effect of surfactants, Bacillus thuringiensis formulations, and plant damage on oviposition by diamond back moth (Lepidoptera: plutellidae). J. Econ. Entomol., 89: 891-897. 


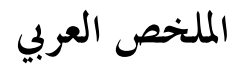

\section{تقييم بعض المر كبات الآمنة بيئياً ضد دودة ورق القطن}

سهام منصور إسماعيل، محمود مرشدى

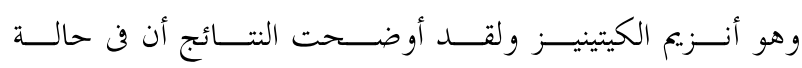

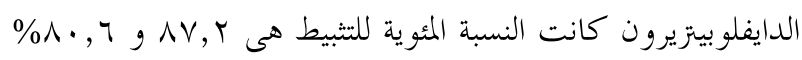
الهدف من البحث هو تقيم التأثير الأبادى للمبيــــ الحيـــى

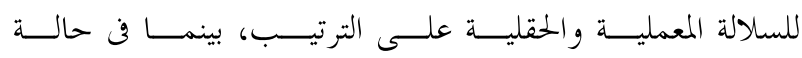

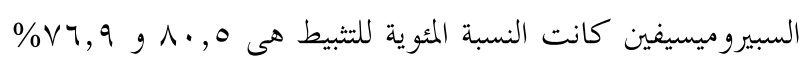

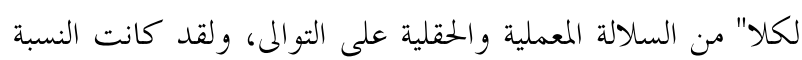

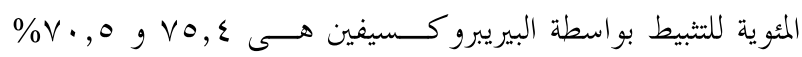

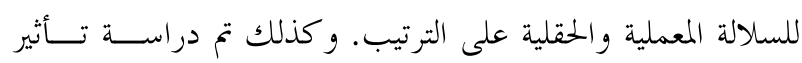

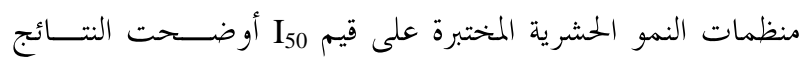
حدوث زيادة في الفعل الأبادى للداييل-rأكس على يرقات العمر المبتر

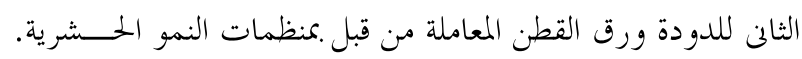

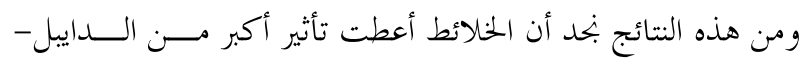

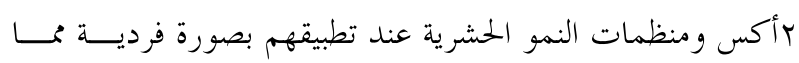

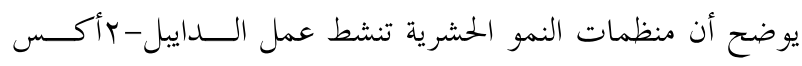

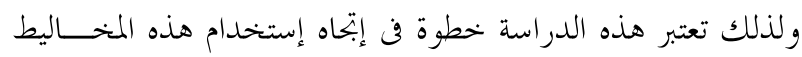
كأحد عناصر المكافحة المتكاملة لدودة ورق القطن حيث إنها أكثر

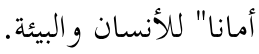

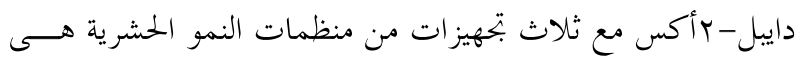

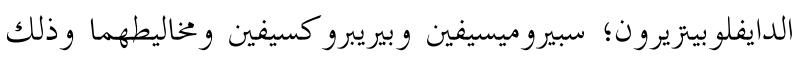
على يرقات العمر الثانى لدودة ورق القطن للسلالة المعملية والحقلية

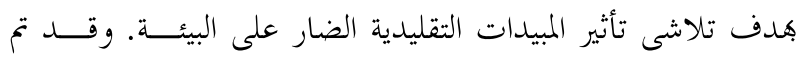

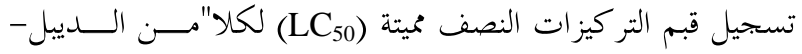
بأكس ومنظمات النمو الحشرية تحت الدراسة بصورة فردية. ثم تم

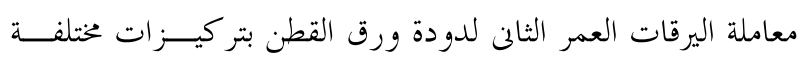

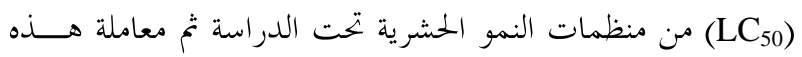

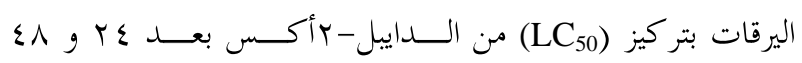

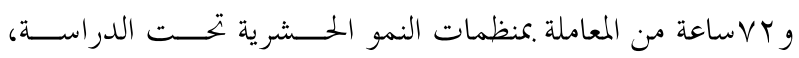

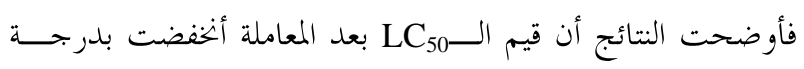

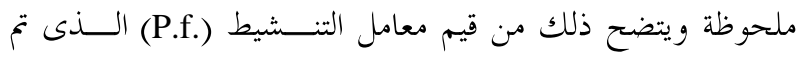

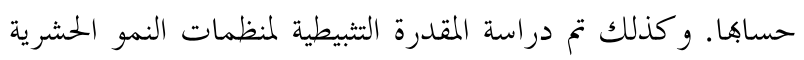
المختبرة على النشاط الأنزيمى لأنزيم هام وحيوى بالنسبة للحشرة المدرة 